\title{
Synthetic Studies towards Communesins: Diastereoselective Oxidative Rearrangement of Aurantioclavine Derivatives
}

\section{$\operatorname{AUTHOR}(\mathrm{S})$ :}

Suetsugu, Satoshi; Tsukano, Chihiro; Takemoto, Yoshiji

\section{CITATION:}

Suetsugu, Satoshi ...[et al]. Synthetic Studies towards Communesins: Diastereoselective Oxidative Rearrangement of Aurantioclavine Derivatives. European Journal of Organic Chemistry 2016, 2016(1): 108-115

\section{ISSUE DATE:}

2016-01

URL:

http://hdl.handle.net/2433/235943

\section{RIGHT:}

This is the peer reviewed version of the following article: Suetsugu Satoshi, Tsukano Chihiro, Takemoto Yoshiji, Synthetic Studies towards Communesins: Diastereoselective Oxidative Rearrangement of Aurantioclavine Derivatives, European Journal of Organic Chemistry, 2016, 1, (108-115), (2016) which has been published in final form at https://doi.org/10.1002/ejoc.201501194. This article may be used for non-commercial purposes in accordance with Wiley Terms and Conditions for Use of Self-Archived Versions.; この論文は出版社版でありません。引用の際には出版社 版をご確認じ利用ください。; This is not the published version. Please cite only the published version. 


\title{
Synthetic Studies towards Communesins: Diastereoselective Oxidative Rearrangement of Aurantioclavine Derivatives
}

\author{
Satoshi Suetsugu, Chihiro Tsukano and Yoshiji Takemoto*[a]
}

\begin{abstract}
Communesins are a heptacyclic class of indole alkaloids bearing two aminal moieties and two contiguous quaternary carbon centers. We have investigated the construction of the pentacyclic skeleton of communesins via the oxidative rearrangement of aurantioclavine derivatives, because aurantioclavine is believed to be a biosynthetic intermediate of the polycyclic communesin alkaloids. The $\mathrm{C} 7$ quaternary carbon center was constructed in a stereoselective manner, while the installation of the $\mathrm{C} 11$ stereocenter required an epimerization process. The isolation of 2ethoxyindolenine prior to the reduction of the nitro group and cyclization was found to be critical to the success of this strategy.
\end{abstract}

\section{Introduction}

Communesins are a heptacyclic class of indole alkaloids bearing two aminal moieties and two contiguous quaternary carbon centers that can isolated from a marine fungal strain of Penicillium species (Figure 1). ${ }^{1,2}$ These alkaloids have been reported to show significant cytotoxicity against P388 lymphocytic leukemia cells $\left(A, B: E D_{50}=3.5\right.$ and $0.45 \mu \mathrm{g} / \mathrm{mL}$ respectively), as well as potent insecticidal activity towards silkworms (B, E: $L D_{50}=5$ and $80 \mu \mathrm{g} / \mathrm{g}$ ). These molecules have also attracted considerable interest as synthetic targets because of their complex structures and significant biological activities. ${ }^{3}$ Several total syntheses have been reported to date for the construction of racemic communesins, including those of $\mathrm{Qin}^{4}$, Weinreb ${ }^{5}, \mathrm{Ma}^{6 \mathrm{a}}$ and Funk. $^{7}$ Furthermore, $\mathrm{Ma}$ et al. ${ }^{\mathrm{bb}}$ also reported the development of an asymmetric total synthesis of communesins. Interestingly, Stoltz and co-workers reported that aurantioclavine, which is a tricyclic alkaloid isolated from Penicillium aurantiovirens, ${ }^{8}$ could be a biosynthetic intermediate of the polycyclic communesin alkaloids. ${ }^{9,10}$ In a separate study, Stoltz et al, ${ }^{11}$ reported a formal synthesis of $( \pm)$-communesin $\mathrm{F}$ using a unified stereodivergent alkylation approach, as well as a biosynthesis-inspired approach from aurantioclavine. Tang et al. ${ }^{12}$ confirmed that communesins can biosynthesized by the coupling of tryptamine and aurantioclavine based on a series of genetic-inactivation studies. ${ }^{12}$

We recently reported the development of an enantioselective total synthesis of aurantioclavine based on a Pd-catalyzed asymmetric allylic amination reaction. ${ }^{13}$ Given that communesins share their core structure with aurantioclavine, it was envisaged that our recently developed route could be

[a] S. Suetsugu, Dr. C. Tsukano, Prof. Dr. Yoshiji Takemoto Graduate School of Pharmaceutical Sciences Kyoto University

Yoshida, Sakyo-ku, Kyoto, 606-8501 (Japan)

E-mail: takemoto@pharm.kyoto-u.ac.jp

Homepage URL: http://www.pharm.kyoto-

u.ac.jp/orgchem/09 eng.html

Supporting information for this article is given via a link at the end of the document.

applied to the asymmetric synthesis of communesins. Furthermore, if we could achieve the synthesis of communesins from intermediate 6 for aurantioclavine, then it would possible to prepare a wide range of synthetic analogs for biological studies using the same synthetic route. With this in mind, we investigated the possibility of extended of our previous methodology to the construction of communesins.

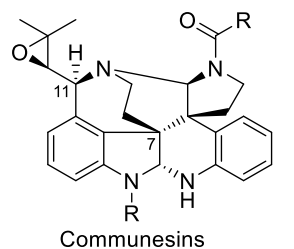

$A \cdot R=R^{\prime}=M e$

$B: R=M e, R^{\prime}=$

$C: R=H, R^{\prime}=$ k

$D: R=C H O, R^{\prime}=\xi$

Figure 1. Communesins and (-)-Aurantioclavine.

It was envisioned that the communesins could be synthesized from pentacyclic compound 1 bearing a $\mathrm{C} 7$ quaternary carbon center. Compound 1 itself could be prepared from 6 via one of two different synthetic routes (Scheme 1). According to the first of these two routes, pentacyclic skeleton 1 could be constructed by the $\mathrm{Pd}$-catalyzed cyclization ${ }^{14}$ of amidine 2 , which could itself be constructed by the $\mathrm{Sml}_{2}$-mediated reductive cyclization ${ }^{15}$ of carbodiimide 3 (route A). It is noteworthy that $\mathrm{Sml}_{2}$-mediated reductive cyclization reactions of this type represent a powerful and reliable strategy for the synthesis of 2 -iminoindolines. The second potential strategy for the construction of compound 1 involved the oxidative rearrangement of the 2-substituted indole 5, which contains the same skeleton as aurantioclavine, to give 4. The subsequent cyclization of 4 would then give the desired pentacyclic compound $\mathbf{1}$ (route B). The use of an oxidative rearrangement reaction for the synthesis of 3,3-disubstituted oxindoles is a well established method in organic chemistry, and this strategy has been used before for the construction of an indole alkaloid. ${ }^{16}$ Notably, the two important intermediates $\mathbf{3}$ and 5 could be derived from common intermediate 6 , which we prepared previously in our synthesis of (-)-aurantioclavine. In this study, we describe our efforts towards the synthesis of the pentacyclic skeleton 1 based on the two synthetic routes described above. The isolation of 2-ethoxylindolenine from the oxidative rearrangement reaction was found to be critical to the success of this strategy, because it prevented the occurrence of any undesired side reactions. 


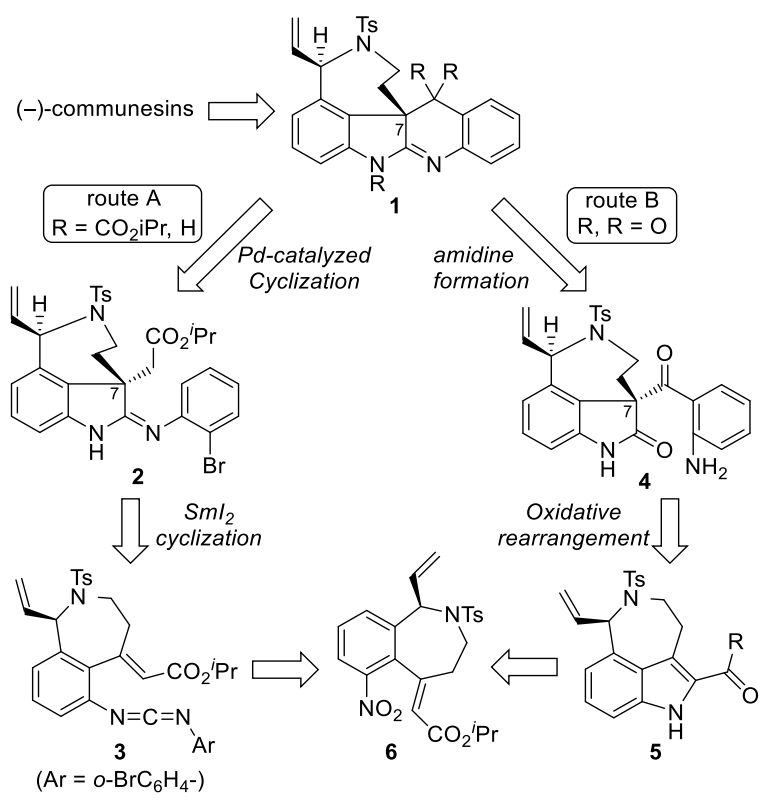

Scheme 1. Retrosynthesis of the pentacyclic core of Communesins.

\section{Results and Discussion}

We initially investigated the synthesis of carbodiimide $3^{13}$ to explore the feasibility of using sequential $\mathrm{Sml}_{2}$-mediated reductive cyclization and $\mathrm{Pd}$-catalyzed cyclization reactions. The reduction of the nitro group in azepane $6^{17}$ gave aniline 7 (Scheme 2). The subsequent treatment of 7 with $0-\mathrm{BrC}_{6} \mathrm{H}_{4} \mathrm{NCO}$ gave the corresponding urea, which was converted to carbodiimide 3 following a dehydration reaction with $\mathrm{CBr}_{4}$ and $\mathrm{PPh}_{3}$. The amidine core bearing the desired quaternary carbon center was successfully constructed using a $\mathrm{Sml}_{2}$-mediated reductive cyclization reaction. ${ }^{14}$ Disappointingly, however, the C7 stereochemistry was the undesired configuration. The formation of the undesired stereochemistry at $\mathrm{C} 7$ can be explained in terms of the differences in the stabilities of the different conformers of compound $\mathbf{3}$ (Figure 2). Conformer $\mathbf{A}$ would be thermodynamically more stable than conformer $\mathbf{B}$ because the Ts and vinyl groups would be axial, which would minimize the steric repulsion between these two groups. With this in mind, the reaction would proceed through conformer $\mathbf{A}$ to give cyclized compound $8 .{ }^{18}$ The subsequent Boc protection of the indoline nitrogen gave compound $\mathbf{9}$ as a single diastereomer and both of these compounds were screened against an extensive series of $\mathrm{Pd}$-catalyzed conditions in an attempt to affect their cyclization to give the desired pentacyclic compound 10. ${ }^{14}$ However, none of the conditions tested provided access to compound 10. For example, the treatment of 9 with $\mathrm{Pd}(\mathrm{OAc})_{2}$, $\mathrm{PPh}_{3}$ and $\mathrm{Cs}_{2} \mathrm{CO}_{3}$ in toluene at $80{ }^{\circ} \mathrm{C}$ gave a complex mixture. Furthermore, the use of other ligands ${ }^{19}$ and bases $^{20}$ also resulted in the decomposition of the starting material. Given that the $\alpha$ position of the ester would be congested under the conditions required of $\mathrm{Pd}$-mediated catalysis, it would be difficult for the Pd-intermediate derived from the oxidative addition of the aryl bromide to $\mathrm{Pd}(0)$ to react with the enolate. With this in mind, we switched our focus the second of the two plans described above (i.e. route $B$, Scheme 1 ), where the fifth ring would be cyclized via the formation of an amidine..$^{5,8}$
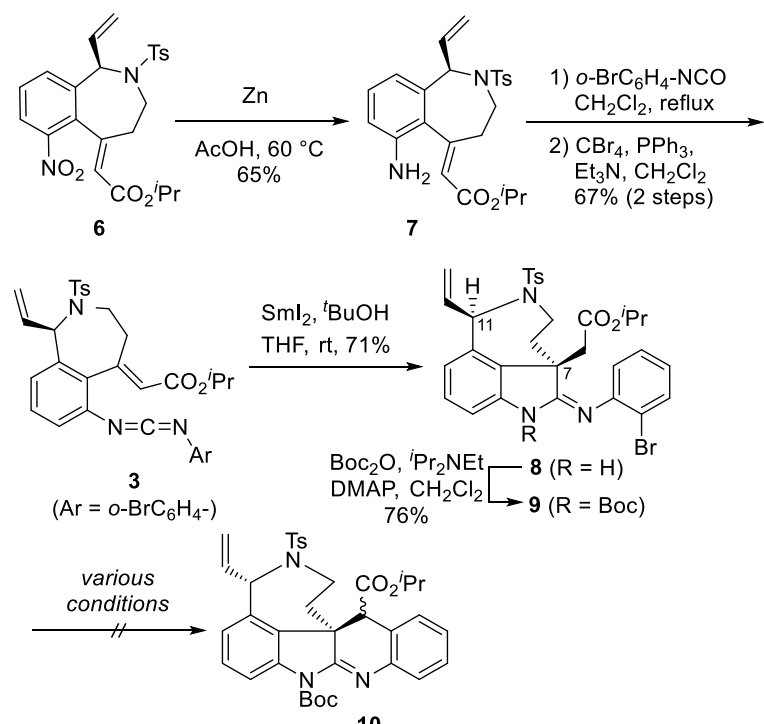

Scheme 2. Attempted formation of the amidine ring by a Pd-catalyzed cyclization.

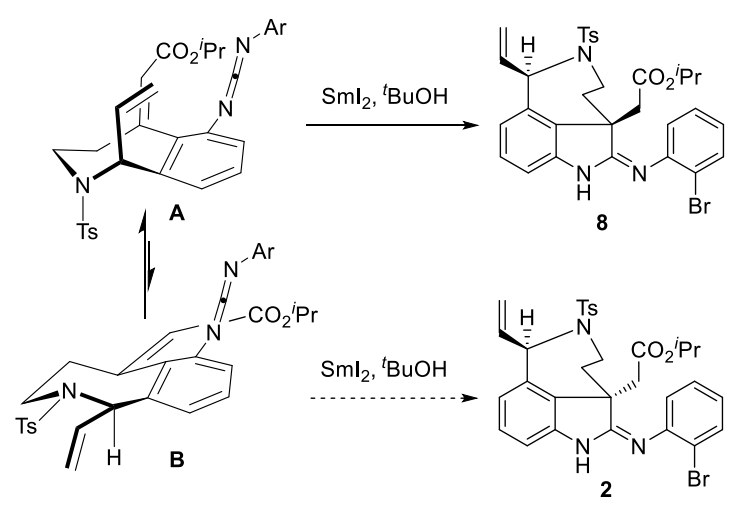

Figure 2. Stereochemistry of $\mathrm{Sml}_{2}$-mediated reductive cyclization of $\mathbf{3}$.

To evaluate the feasibility of the second strategy, we prepared several 2-substituted indoles for the oxidative rearrangement reaction. The treatment of compound 6 with $\mathrm{P}(\mathrm{OEt})_{3}$ at $170{ }^{\circ} \mathrm{C}$ gave ester $\mathbf{5 a}$, which was subjected to a hydrolysis reaction followed by a condensation reaction with $\mathrm{N}$ methoxymethylamine to give Weinreb amide $5 c$ (Scheme 3). The subsequent reduction of $5 \mathbf{a}$ with DIBAL-H, followed by the allylic oxidation of the resulting alcohol gave aldehyde $\mathbf{5 b}$. The nucleophilic addition of an in situ generated Grignard reagent to the aldehyde gave the corresponding alcohol 11, which was treated with $\mathrm{MnO}_{2}$ to give ketone 5d. Compound 12 was also 
prepared from alcohol $\mathbf{1 1}$ to determine the importance of the carbonyl group.

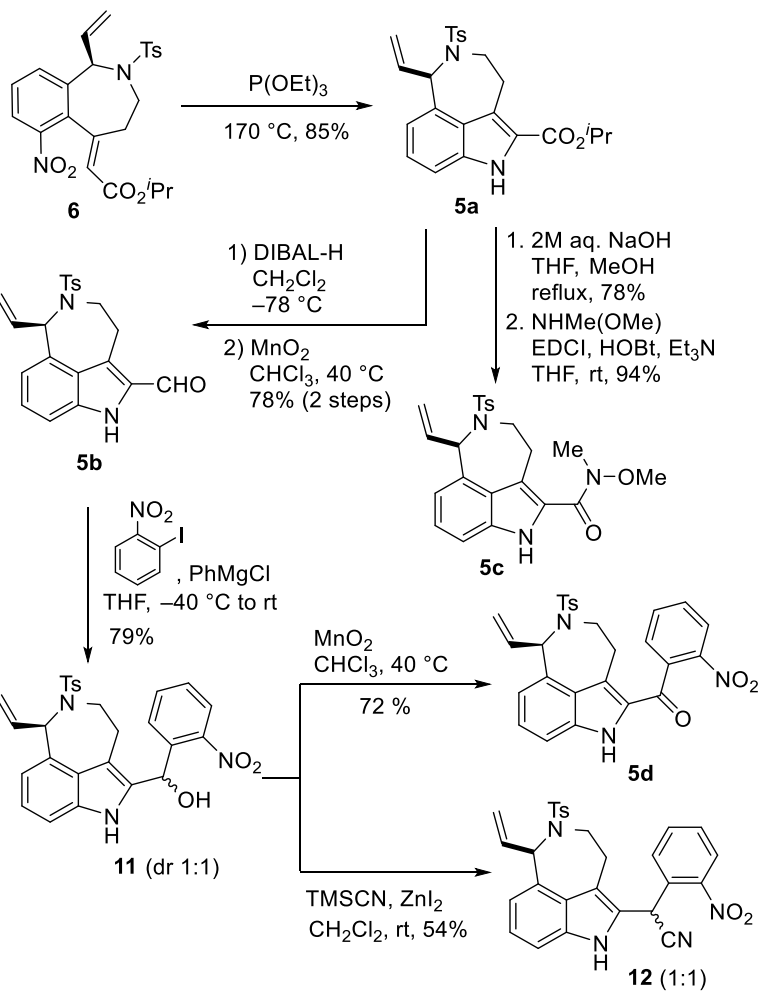

Scheme 3. Synthesis of substrates $5 \mathbf{a}-\mathbf{d}$ and 12 for the oxidative rearrangement.

With a series of 2-substituted indoles in hand (5a-d and 12), we proceeded to investigate the oxidative rearrangement of these compounds for the synthesis of oxindoles bearing a quaternary carbon center at $\mathrm{C} 7$. The chlorination of ester $5 \mathrm{a}$ with ${ }^{\mathrm{t}} \mathrm{BuOCl}$, followed by the treatment of the resulting species with $1 \mathrm{M} \mathrm{HCl}$ in $\mathrm{EtOH}-\mathrm{CH}_{2} \mathrm{Cl}_{2}$ gave the desired oxindole 4a (Table 1, entry 1). Although the reaction of aldehyde $\mathbf{5 b}$ under the same conditions gave oxindole 13 instead of the desired compound $\mathbf{4 b}$, Weinreb amide $5 \mathrm{c}$ was converted to $4 \mathrm{c}$ in $62 \%$ yield (Table 1 , entries 2 and 3 ). These results were consistent with the results reported by Moody. ${ }^{16 a}$ Compound $\mathbf{1 3}$ was most likely produced by the retro-Claisen-type reaction of $\mathbf{4 b}$ following its oxidative rearrangement. Ketone $\mathbf{5 d}$ reacted smoothly under these conditions to give the desired compound $\mathbf{4 d}$. In contrast, the reaction of 12, which did not contain a carbonyl group, gave a complex mixture of products (Table 1, entries 4 and 5). These results therefore indicated that the presence of a carbonyl group was important for stabilizing the transition state of the rearrangement step.
Table 1. Oxidative rearrangement of compounds $5 a-d$ and 12.

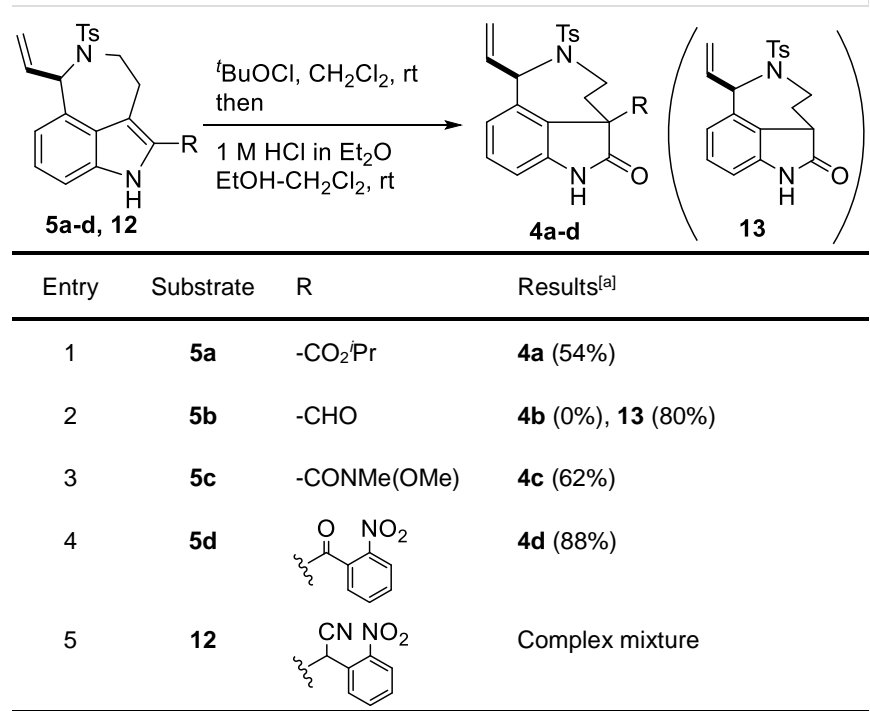

[a] Isolated yield.

We then attempted to access a cyclized precursor from compounds $\mathbf{4 c}$ and $\mathbf{4 d}$ (Scheme 4$)$. The protection of the indole nitrogen in 4c with a methyl group gave compound 14, which was treated with an in situ-generated aryl lithium reagent prepared from iodide $\mathbf{1 5}$ and ${ }^{\mathrm{B}} \mathrm{BuLi}$ in an attempt to prepare compound 16. However, this reaction resulted in the decomposition of the substrate. The reaction of $\mathbf{4 d}$ with zinc in acetic acid led to the reduction of the nitro group followed by the cleavage of the $\mathrm{C}-\mathrm{C}$ bond at the 3-position of the oxindole core to give compound 13. The cleavage of the $\mathrm{C}-\mathrm{C}$ bond was attributed to the delocalization of the electron pair of the newly formed aniline 19. ${ }^{21}$ Furthermore, the reduction of ketone 17, which was prepared from $\mathbf{4 d}$, also gave product $\mathbf{1 3}$ via a similar retro-aldol-type reaction through compound 20 . Based on these results, we concluded that the oxindole moiety was the cause of the undesired retro-aldol-type reactions, and that it would therefore need to be protected prior to the reduction of nitro and carbonyl groups. 
<smiles>[R]N1C(=O)C2(C(=O)N(C)C)CC[Y5]C(C=C)c3cccc1c32</smiles>

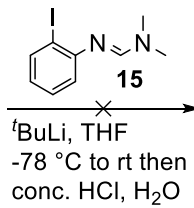

$\mathrm{NaH}, \mathrm{Mel}-\mathbf{4 c}(\mathrm{R}=\mathrm{H})$

$\mathrm{DMF}, 89 \% \longrightarrow 14(\mathrm{R}=\mathrm{Me})$ decomp.<smiles>C=CC1[13CH2]C[C@]2(C(=O)c3ccccc3N)C(=O)N(C)c3cccc1c32</smiles>

16<smiles>C=CC1[Y5]CC[C@]2(C(=O)c3ccccc3[N+](=O)[O-])C(=O)Nc3cccc1c32</smiles>

4d

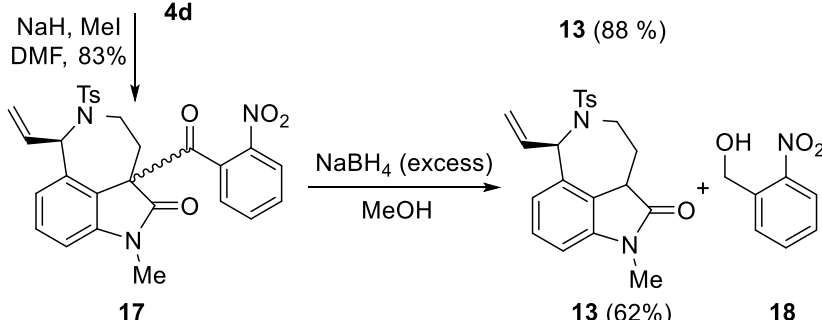<smiles>C=CC1NC(=O)C2(CC(=O)c3ccccc3N)CCCCc3cccc1c32</smiles>
19

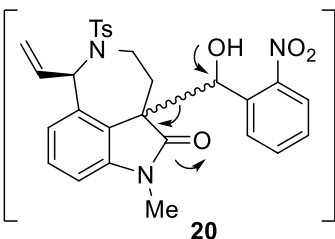

Scheme 4. Attempted derivatization of $\mathbf{4 c}$ and $\mathbf{4 d}$.

To address the issues described above, we selected 2alkoxyindolenine, which is an intermediate of the oxidative rearrangement reaction, as a suitable protecting group for the reduction of the nitro group. Given that 2-ethoxyindolenine $\mathbf{2 1}$ was not isolated during the course of our initial evaluation of the oxidative rearrangement reaction, as shown in Table 1, it was anticipated that this compound would be unstable under the reaction conditions or its subsequent purification by column chromatography over silica gel. With this in mind, the reduction of 21 was performed immediately after its formation and concentration without any further purification. Although the reduction of 21 with $\mathrm{SnCl}_{2}$ in toluene gave a complex mixture, the use of $\mathrm{Zn}$ gave compounds 13 and $23^{22}$ in 54 and $14 \%$ yields, respectively (Table 2 , entries 1 and 2). When the reduction was conducted in the presence of $\mathrm{Fe}$, the reaction gave a small amount of $\mathbf{2 3}$ as part of a complex mixture (Table 2, entry 3). When isopropanol was used instead of ethanol to stabilize the 2-alkoxyindolenine intermediate, 2isopropoxyindolenine was obtained as an intermediate. However, the oxidative rearrangement of this intermediate did not proceed smoothly, and the subsequent treatment of this material with $\mathrm{Zn}$ gave a complex mixture (Table 2, entry 4 ). The reduction was also conducted without the concentration of the 2ethoxyindolenine solution, but gave only compound 23 in $47 \%$ yield (Table 2, entry 5). We speculated that the by-product 23 would be produced by the formation of the pentacyclic skeleton
22, followed by a retro-Claisen-type reaction and the formation of an indoloquinazolinone (Scheme 5). In fact, compound 22 was observed in the ${ }^{1} \mathrm{H}$ NMR spectrum of a crude reaction mixture when a shorter reaction time was used. Furthermore, it was possible to isolate this material together with 2ethoxyindolenine 21 by silica gel column chromatography in low yields of 21 and $28 \%$, respectively (Table 2 , entry 6 ). After the isolation of $\mathbf{2 1}$, it was also confirmed that $\mathbf{2 1}$ could be readily converted to indoloquinazolinone $\mathbf{2 3}$ under acidic conditions (Scheme 5).

Table 2. Investigation of the construction of the pentacyclic skeleton.

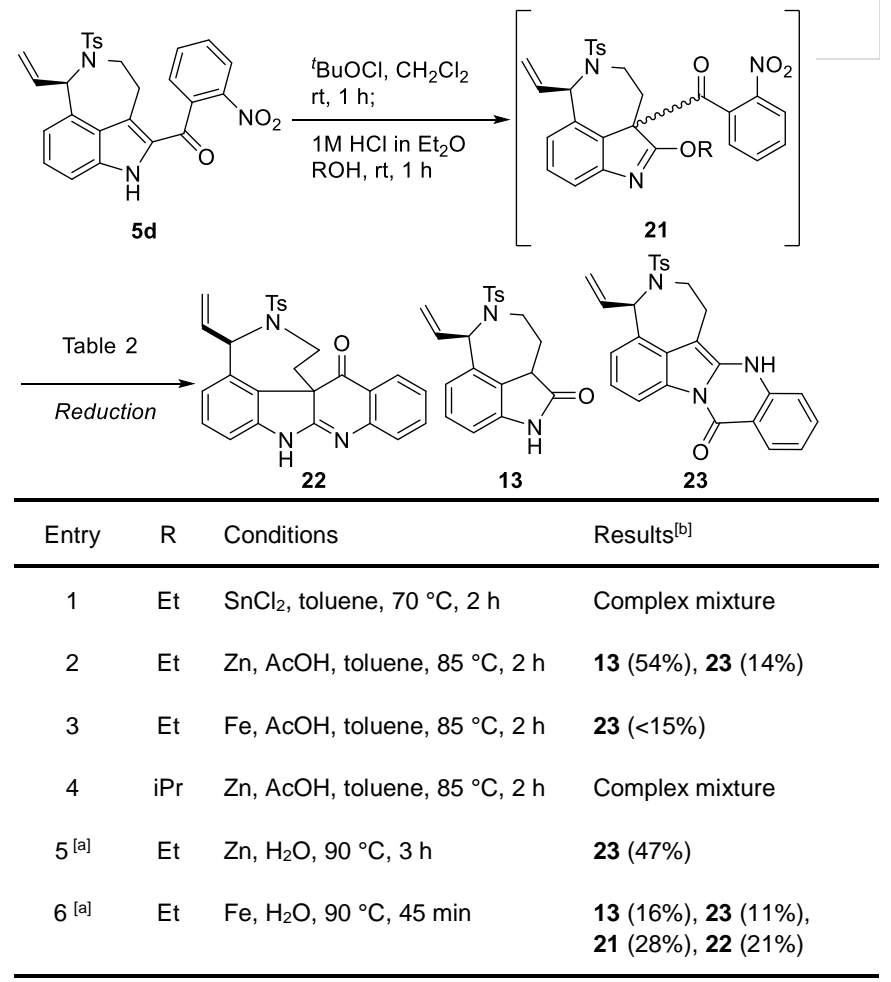

[a] Conc. $\mathrm{HCl}$ was used for the first step and the solvent was not evaporated before the reduction. [b] Isolated yield. 


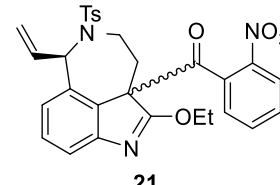

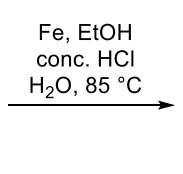<smiles>C=CC1Cc2ccccc2NC(=N)C12CC(=O)c1ccccc1N2</smiles><smiles>C=CC([Al])c1cccc2[nH]c(Nc3ccccc3C(=O)O)c(CC)c12</smiles>

25 22

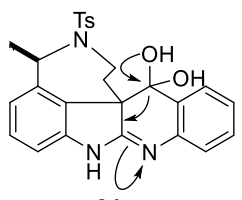

24<smiles>COCCO</smiles>

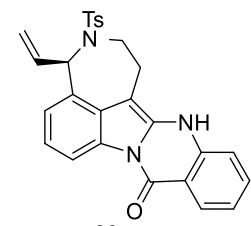

Scheme 5. Conversion of 2-ethoxyindolenine $\mathbf{2 1}$ to indoloquinazolinone 23 .

Finally, we successfully isolated 2-ethoxyindolenine 21 in $98 \%$ yield by the treatment of $\mathbf{5} \mathbf{d}$ with ${ }^{\mathrm{B}} \mathrm{BuOCl}$ followed by conc. $\mathrm{HCl}$ in $\mathrm{EtOH}$. The subsequent reaction of $\mathbf{2 1}$ under mildly acidic conditions (i.e., $\mathrm{Fe}$ and solid $\mathrm{NH}_{4} \mathrm{Cl}$ in $\mathrm{EtOH}-\mathrm{H}_{2} \mathrm{O}$ at $90{ }^{\circ} \mathrm{C}$ ) gave the pentacyclic compound 22 in $43 \%$ yield without the formation of any of the undesired indoloquinazoline 23 (Scheme 6). The stereochemistry at $\mathrm{C} 7$ was determined after the Boc protection and subsequent reduction of the amidine nitrogen to give $\mathbf{2 6}$. The NOESY spectra of $\mathbf{2 6}$ revealed that $\mathrm{H}^{\mathrm{a}}$ was correlated with $\mathrm{H}^{\mathrm{b}}$ and $\mathrm{H}^{\mathrm{c}}$, and that $\mathrm{H}^{\mathrm{d}}$ was correlated with $\mathrm{H}^{\mathrm{e}}$ and $\mathrm{H}^{\mathrm{f}}$ (Figure 3 ). These results therefore indicated that the $\mathrm{C} 7$ stereochemistry was $R$, and that the epimerization of $\mathrm{C} 11$ would be required for the construction of the communesin core. ${ }^{23}$<smiles>C=CC1C=C2NC(C(=O)c3ccccc3[N+](=O)[O-])=C2CCN1</smiles>

$5 d$

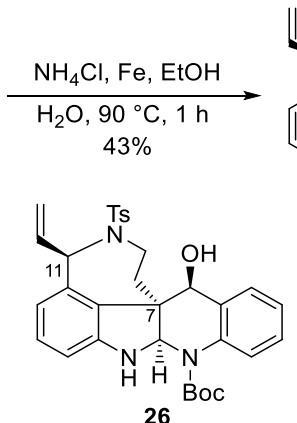

Scheme 6. Synthesis of the pentacyclic skeleton 22 .

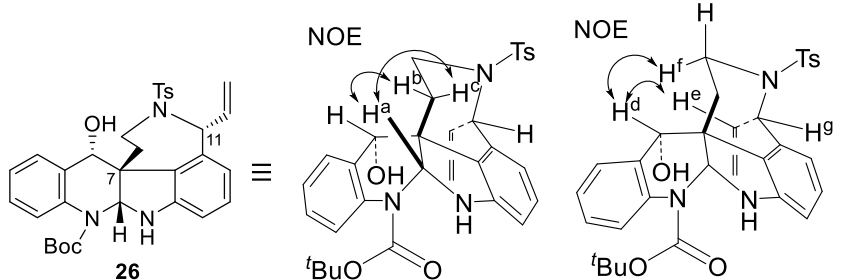

Figure 3. NOESY experiments with compound 26

Based on the results of several previous reports, ${ }^{16 b, c, f, i-1}$ the diastereoselectivity of the oxidative rearrangement can be rationalized as follows. The treatment of $5 \mathbf{d}$ with ${ }^{t} \mathrm{BuOCl}$ would give 3-chloroindolenine $\mathbf{C}$, which would be thermodynamically more stable than $\mathbf{D}$ (Scheme 7). The protonation of $\mathbf{C}$ and formation of chloronium cation $\mathbf{E}$ would be followed by the addition of $\mathrm{EtOH}$ to give intermediate $\mathbf{F}$. In this case, the rearrangement would occur via an $S_{N} 1$ reaction rather than an $\mathrm{S}_{\mathrm{N}} 2$ reaction. The elimination of the chloride ion and the diastereoselective rearrangement of the carboaryl moiety would therefore proceed through intermediate $\mathbf{G}$ to give 2ethoxyindolenine $\mathbf{2 1}$.

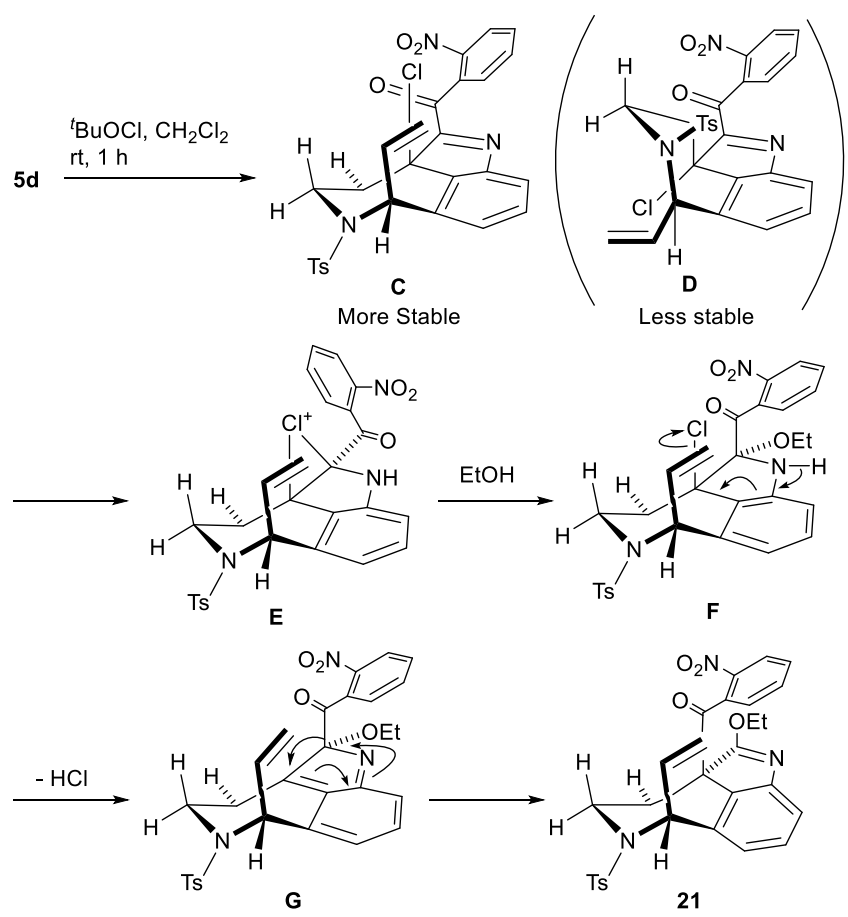

Scheme 7. Stereochemistry of oxidative rearrangement of $\mathbf{5 d}$.

\section{Conclusions}

We have investigated the construction of the pentacyclic skeleton of the communesins through two synthetic strategies, including i) a $\mathrm{Sml}_{2}$-mediated reductive cyclization and $\mathrm{Pd}$ - 
catalyzed cyclization strategy; and ii) an oxidative rearrangement strategy. Although the first of these two strategies was found to be unsuccessful, the desired pentacyclic skeleton was successfully constructed using the second strategy. The C7 quaternary carbon center was constructed in a stereoselective manner based on an oxidative rearrangement reaction, while the $\mathrm{C} 11$ stereocenter required an epimerization step to afford the desired stereochemistry. Finally, the isolation of 2-ethoxyindolenine prior to the reduction of its nitro group was found to be critical to the success of the cyclization reaction. We are currently investigating the epimerization of the $\mathrm{C} 11$ carbon center with the aim of developing an enantioselective total synthesis of the communesins.

\section{Experimental Section}

General: All of the non-aqueous reactions were carried out under a positive atmosphere of argon in dried glassware. Analytical thin-layer chromatography was performed with Silica gel 60 (Merck). Silica gel column chromatography was performed over Kanto silica gel 60 (particle size, 63-210 $\mu \mathrm{m}$ ) and Fuji silysia Chromatorex BW-300. Proton nuclear magnetic resonance ( ${ }^{1} \mathrm{H}$ NMR) spectra were recorded on a JEOL JNMECA 500 system (JEOL, Japan) at $500 \mathrm{MHz}$ or a JEOL JNM-AL 400 system at $400 \mathrm{MHz}$. Chemical shifts have been reported relative to $\mathrm{Me}_{4} \mathrm{Si}$ $(\delta \quad 0.00)$ in $\mathrm{CDCl}_{3}$. The multiplicities of the signals in the spectra have been described by one or more of the following: s (singlet); $d$ (doublet); $t$ (triplet); q (quartet); m (multiplet); br (broad). Carbon nuclear magnetic resonance $\left({ }^{13} \mathrm{C}\right.$ NMR) spectra were recorded on a JEOL JNM-ECA 500 system at $126 \mathrm{MHz}$ or a JEOL JNM-AL 400 system at $100 \mathrm{MHz}$. Chemical shifts have been reported relative to $\mathrm{CDCl}_{3}(\delta$ 77.0). Infrared spectra were recorded on a FT/IR-4100 Fourier-transform infrared spectrometer with attenuated total reflectance (JASCO, Japan). Low and High resolution mass spectra were recorded on JEOL JMS-HX/HX 110A mass spectrometer for FAB-MS and a Shimadzu LCMS-IT-TOF (Shimadzu, Japan) for ESI-MS.

Material: Anhydrous $\mathrm{CH}_{2} \mathrm{Cl}_{2}$, THF, methanol and ethanol were purchased from KANTO Chemical Co. Aldrich and Wako chemicals. The reagents and materials used in the current study were obtained from Tokyo Chemical Industry Co., Ltd, Aldrich Inc. and several other commercial suppliers and used without further purification.

Compound 5a: A solution of 6 (792 mg, $1.69 \mathrm{mmol})$ in $\mathrm{P}(\mathrm{OEt})_{3}(4.0 \mathrm{~mL})$ was stirred at $170{ }^{\circ} \mathrm{C}$ for $3 \mathrm{~h}$. The mixture was then concentrated under reduced pressure and purified by flash column chromatography over neutral silica gel (20\% EtOAc/hexane) to give 5 a $(633 \mathrm{mg}, 85 \%)$ as a colorless oil: $[\alpha]_{D^{21}}-51.7^{\circ}\left(c 1.12, \mathrm{CHCl}_{3}\right) ;{ }^{1} \mathrm{H} \mathrm{NMR}\left(500 \mathrm{MHz}, \mathrm{CDCl}_{3}\right) \delta$ $9.04(1 \mathrm{H}, \mathrm{br} \mathrm{s}), 7.69(2 \mathrm{H}, \mathrm{d}, J=8.3 \mathrm{~Hz}), 7.27-7.26(1 \mathrm{H}, \mathrm{m}), 7.20(1 \mathrm{H}, \mathrm{t}, J$ $=7.7 \mathrm{~Hz}), 7.15(2 \mathrm{H}, \mathrm{d}, J=8.0 \mathrm{~Hz}), 6.84(1 \mathrm{H}, \mathrm{d}, J=7.2 \mathrm{~Hz}), 6.04(1 \mathrm{H}, \mathrm{s})$, $5.77(1 \mathrm{H}$, ddd, $J=17.1,10.4,4.5 \mathrm{~Hz}), 5.30-5.25(1 \mathrm{H}, \mathrm{m}), 5.13(1 \mathrm{H}, \mathrm{d}, J=$ $10.3 \mathrm{~Hz}), 4.68(1 \mathrm{H}, \mathrm{d}, J=17.3 \mathrm{~Hz}), 4.05-4.03(1 \mathrm{H}, \mathrm{m}), 3.60-3.54(2 \mathrm{H}, \mathrm{m})$, 3.44-3.37 (1H, m), $2.34(3 \mathrm{H}, \mathrm{s}), 1.39(3 \mathrm{H}, \mathrm{d}, J=2.6 \mathrm{~Hz}), 1.38(3 \mathrm{H}, \mathrm{d}, J=$ $2.6 \mathrm{~Hz}) .{ }^{13} \mathrm{C}$ NMR $\left(126 \mathrm{MHz}, \mathrm{CDCl}_{3}\right) \delta 161.7,142.9,138.0,137.7,136.8$, $134.0,129.3,126.9,125.2$, 124.5, 123.2, 121.6, 120.2, 119.1, 110.6, 68.5, 63.8, 43.2, 29.8, 22.0 (x2), 21.3; IR (ATR, cm-1) 3344, 2980, 1693, 1452, 1338, 1248, 1156, 1094, 916, 751; HRMS (ESI) calcd for $\mathrm{C}_{24} \mathrm{H}_{27} \mathrm{~N}_{2} \mathrm{O}_{4} \mathrm{~S}[\mathrm{M}+\mathrm{H}]^{+}$439.1686; Found: $m / z$ 439.1668

Compound 5b : To a solution of $5 \mathrm{a}(200 \mathrm{mg}, 0.456 \mathrm{mmol})$ in $\mathrm{CH}_{2} \mathrm{Cl}_{2}$ (5 $\mathrm{mL})$ was added DIBAL-H $(1 \mathrm{M}$ in hexane, $1.6 \mathrm{ml}, 1.6 \mathrm{mmol})$ at $-78^{\circ} \mathrm{C}$ and the mixture was stirred at $-78^{\circ} \mathrm{C}$ for $1 \mathrm{~h}$. The reaction mixture was then quenched with satd. aq. $\mathrm{Na} / \mathrm{K}$ tartrate and stirred vigorously at room temperature for $1 \mathrm{~h}$. The mixture extracted with EtOAc, washed with brine and dried over $\mathrm{Na}_{2} \mathrm{SO}_{4}$. Concentration under reduced pressure gave the crude alcohol without purification. To a solution of the crude alcohol in $\mathrm{CHCl}_{3}(20 \mathrm{~mL})$ was added $\mathrm{MnO}_{2}(705 \mathrm{mg}, 8.11 \mathrm{mmol})$ at room temperature, and the mixture was stirred at $40{ }^{\circ} \mathrm{C}$ for $1 \mathrm{~h}$. After reaction mixture was filtered through a pad of Celite, and concentration under reduced pressure. The crude material was purified by flash column chromatography on silica gel (30\% EtOAc/hexane) to give $5 \mathbf{b}(124 \mathrm{mg}$, $76 \%, 2$ steps) as a white amorphous: $[\alpha]_{D}{ }^{22}-42.8^{\circ}\left(c 0.66, \mathrm{CHCl}_{3}\right) ;{ }^{1} \mathrm{H}$ $\operatorname{NMR}\left(\mathrm{CDCl}_{3}\right) \delta 9.94(1 \mathrm{H}, \mathrm{s}), 8.94(1 \mathrm{H}$, br s), $7.69(2 \mathrm{H}, \mathrm{d}, J=6.9 \mathrm{~Hz})$, 7.30-7.28 (2H, m), $7.19(2 \mathrm{H}, \mathrm{d}, J=7.4 \mathrm{~Hz}), 6.90-6.89(1 \mathrm{H}, \mathrm{m}), 6.06(1 \mathrm{H}$, br s), 5.79-5.75 $(1 \mathrm{H}, \mathrm{m}), 5.16(1 \mathrm{H}, \mathrm{d}, J=10.3 \mathrm{~Hz}), 4.67(1 \mathrm{H}, \mathrm{d}, J=17.2$ $\mathrm{Hz}), 4.11-4.08(1 \mathrm{H}, \mathrm{m}), 3.65(1 \mathrm{H}, \mathrm{td}, J=10.2,5.1 \mathrm{~Hz}), 3.53-3.49(2 \mathrm{H}, \mathrm{m})$ $2.37(3 \mathrm{H}, \mathrm{s}) ;{ }^{13} \mathrm{C} \mathrm{NMR}\left(126 \mathrm{MHz}, \mathrm{CDCl}_{3}\right) \delta 180.3,143.2,138.4,137.9$ $137.4,135.4,131.3,129.5,127.0,126.8,126.2,125.2,120.8,119.6$ 111.2, 63.6, 43.0, 27.6, 21.5; IR (film, $\mathrm{cm}^{-1}$ ) 3317, 2981, 2918, 1649, 1574, 1535, 1460, 1369, 1341, 1278, 1236, 1158, 1092, 1019, 974, 915, 876, 755, 736, 691, 667; HRMS (FAB) calcd for $\mathrm{C}_{21} \mathrm{H}_{21} \mathrm{~N}_{2} \mathrm{O}_{3} \mathrm{~S}[\mathrm{M}+\mathrm{H}]$ 381.1273; Found: $m / z$ 381.1272.

Compound 5c: To a solutions of $5 \mathrm{a}(150 \mathrm{mg}, 0.379 \mathrm{mmol})$ in $\mathrm{MeOH}(4$ $\mathrm{mL})$ and THF $(4 \mathrm{~mL})$ was added a solutions of $2 \mathrm{M}$ aq. $\mathrm{NaOH}(4 \mathrm{~mL})$. The mixture was refluxed for $1 \mathrm{~h}$, and then concentration under reduced pressure until THF and $\mathrm{MeOH}$ were removed. The residue was acidified with $2 \mathrm{M}$ aq. $\mathrm{HCl}(4 \mathrm{~mL})$ and extracted with EtOAc, dried over $\mathrm{Na}_{2} \mathrm{SO}_{4}$. After concentration under reduced pressure, a crude carboxylic acid was obtained as a white solid. To a solution of crude in THF $(8 \mathrm{~mL})$ was added $\mathrm{NHMe}(\mathrm{OMe})$ (56 mg, $0.568 \mathrm{mmol}$ ), EDCl (109 mg, $0.568 \mathrm{mmol}$ ), HOBt $(77 \mathrm{mg}, 0.568 \mathrm{mmol})$ and $\mathrm{Et}_{3} \mathrm{~N}(0.159 \mathrm{~mL}, 1.14 \mathrm{mmol})$ at room temperature. This mixture was stirred at room temperature for $5 \mathrm{~h}$. The reaction mixture was concentrated under reduced pressure and purified by flash column chromatography on silica gel (30\% EtOAc/hexane) to give the mixture of $5 \mathrm{c}(156 \mathrm{mg}, 94 \%)$ as a white amorphous: [ $\alpha]_{\mathrm{D}}{ }^{22}$ $39.4^{\circ}\left(c 0.27, \mathrm{CHCl}_{3}\right) ;{ }^{1} \mathrm{H}$ NMR $\left(500 \mathrm{MHz}, \mathrm{CDCl}_{3}\right) \delta 9.19(1 \mathrm{H}, \mathrm{br} \mathrm{s}), 7.68$ $(2 \mathrm{H}, \mathrm{d}, J=8.3 \mathrm{~Hz}), 7.26-7.21(2 \mathrm{H}, \mathrm{m}), 7.14(2 \mathrm{H}, \mathrm{d}, J=8.0 \mathrm{~Hz}), 6.88(1 \mathrm{H}$ d, $J=6.9 \mathrm{~Hz}), 6.09(1 \mathrm{H}, \mathrm{s}), 5.84-5.81(1 \mathrm{H}, \mathrm{m}), 5.14(1 \mathrm{H}, \mathrm{d}, J=10.3 \mathrm{~Hz})$, $4.71(1 \mathrm{H}, \mathrm{d}, J=16.9 \mathrm{~Hz}), 4.01(1 \mathrm{H}, \mathrm{d}, J=14.9 \mathrm{~Hz}), 3.68(3 \mathrm{H}, \mathrm{s}), 3.63$ $3.53(2 \mathrm{H}, \mathrm{m}), 3.41-3.34(4 \mathrm{H}, \mathrm{m}), 2.34(3 \mathrm{H}, \mathrm{s}) ;{ }^{13} \mathrm{C} \mathrm{NMR}(126 \mathrm{MHz}$ $\left.\mathrm{CDCl}_{3}\right) \delta 161.9,142.7,138.2,138.0,136.4,133.8,129.5,129.3,127.0$, $124.7,124.2,123.7,122.5,120.2,119.0,110.5,63.8,61.8,43.6,33.3$, $29.5,21.4$; IR (ATR, $\mathrm{cm}^{-1}$ ) 3375, 2932, 1732, 1633, 1445, 1338, 1240 1156, 1094; HRMS (ESI) calcd for $\mathrm{C}_{23} \mathrm{H}_{26} \mathrm{~N}_{3} \mathrm{O}_{4} \mathrm{~S}[\mathrm{M}+\mathrm{H}]^{+} 440.1654$ Found: $m / z 440.1639$

Compound 11: To a solution of 2-iodo-nitrobenzene (288 mg, 1.16 $\mathrm{mmol})$ in dry THF $(3 \mathrm{~mL})$ was added $\mathrm{PhMgCl}(2 \mathrm{M}$ in toluene, $0.607 \mathrm{~mL}$, $1.22 \mathrm{mmol}$ ) at $-40{ }^{\circ} \mathrm{C}$, and the mixture was stirred at $-40{ }^{\circ} \mathrm{C}$ for $15 \mathrm{~min}$. The red mixture was then added the solution $5 \mathbf{b}(200 \mathrm{mg}, 0.526 \mathrm{mmol})$ in THF $(3 \mathrm{~mL})$ at $-40{ }^{\circ} \mathrm{C}$ and stirred at room temperature for $30 \mathrm{~min}$. The reaction mixture was then quenched with satd. aq. $\mathrm{NH}_{4} \mathrm{Cl}$, extracted with EtOAc, washed with water and brine, dried over $\mathrm{Na}_{2} \mathrm{SO}_{4}$. After concentration under reduced pressure, purification by flash column chromatography on silica gel (20\% EtOAc/hexane) gave 11 (209 mg, $79 \%$, a $1: 1$ diastereomeric mixture) as a pale yellow amorphous: ${ }^{1} \mathrm{H}$ NMR $\left(500 \mathrm{MHz} \mathrm{CDCl}_{3}\right) \delta 8.67(0.5 \mathrm{H}$, br s), $8.28(0.5 \mathrm{H}$, br s), 7.99-7.97 $(1 \mathrm{H}, \mathrm{m}), 7.66-7.58(3 \mathrm{H}, \mathrm{m}), 7.54-7.47(1 \mathrm{H}, \mathrm{m}), 7.28-7.27(1 \mathrm{H}, \mathrm{m}), 7.20-$ $7.07(4 \mathrm{H}, \mathrm{m}), 6.85-6.83(1 \mathrm{H}, \mathrm{m}), 6.49-6.47(1 \mathrm{H}, \mathrm{m}), 6.07-6.04(1 \mathrm{H}, \mathrm{m})$, 5.82-5.66 (1H, m), 5.13-5.08 (1H, m), $4.74(0.5 \mathrm{H}, \mathrm{d}, J=17.2 \mathrm{~Hz}), 4.63$ $(0.5 \mathrm{H}, \mathrm{d}, J=17.2 \mathrm{~Hz}), 3.94-3.91(1 \mathrm{H}, \mathrm{m}), 3.54-3.49(2 \mathrm{H}, \mathrm{m}), 3.10-3.07$ $(1 \mathrm{H}, \mathrm{m}), 2.74-2.66(1 \mathrm{H}, \mathrm{m}), 2.37-2.36(3 \mathrm{H}, \mathrm{m}) ;{ }^{13} \mathrm{C} \mathrm{NMR}(126 \mathrm{MHz}$ $\left.\mathrm{CDCl}_{3}\right) \delta 137.6,134.1,133.9,132.3,129.9,129.5,129.3,129.2,127.0$ (x2), 125.0, 121.6, 121.5, 119.8, 119.2, 119.0, 110.8, 110.0, 109.9, 65.4, 64.1, 43.5, 28.3, 27.6, 21.4; IR (film, $\mathrm{cm}^{-1}$ ) 3414, 3027, 2942, 1598, 1526, 
1445, 1337, 1228, 1156, 1018, 790, 751, 666; HRMS (FAB) calcd for $\mathrm{C}_{27} \mathrm{H}_{25} \mathrm{~N}_{3} \mathrm{O}_{5} \mathrm{~S}[\mathrm{M}]^{+}$503.1515; Found: $m / z$ 503.1533.

Compound 5d: To a solution of $11(201 \mathrm{mg}, 0.40 \mathrm{mmol})$ in $\mathrm{CHCl}_{3}(20$ $\mathrm{mL}$ ) was added $\mathrm{MnO}_{2}(696 \mathrm{mg}, 8.0 \mathrm{mmol}$ ) at room temperature, and the mixture was stirred at $40{ }^{\circ} \mathrm{C}$ for $1 \mathrm{~h}$. After the reaction mixture was filtered through a pad of Celite, and concentration under reduced pressure. The crude material was purifed by flash column chromatography on silica gel ( $40 \% \mathrm{EtOAc/hexane)}$ to give $\mathbf{5 d}(145 \mathrm{mg}, 72 \%)$ as a yellow amorphous: $[\alpha]_{D}{ }^{22}-59.8^{\circ}\left(c 0.44, \mathrm{CHCl}_{3}\right) ;{ }^{1} \mathrm{H}$ NMR $\left(500 \mathrm{MHz}, \mathrm{CDCl}_{3}\right) \delta 9.16(1 \mathrm{H}, \mathrm{s})$, $8.26(1 \mathrm{H}, \mathrm{d}, J=8.3 \mathrm{~Hz}), 7.81-7.78(1 \mathrm{H}, \mathrm{m}), 7.72-7.69(1 \mathrm{H}, \mathrm{m}), 7.55(2 \mathrm{H}$, $\mathrm{d}, J=8.3 \mathrm{~Hz}), 7.42(1 \mathrm{H}, \mathrm{d}, J=7.4 \mathrm{~Hz}), 7.28-7.26(2 \mathrm{H}, \mathrm{m}), 7.12(2 \mathrm{H}, \mathrm{d}, J$ $=8.3 \mathrm{~Hz}), 6.87-6.87(1 \mathrm{H}, \mathrm{m}), 6.01(1 \mathrm{H}, \mathrm{s}), 5.77-5.74(1 \mathrm{H}, \mathrm{m}), 5.15(1 \mathrm{H}, \mathrm{d}$, $J=10.3 \mathrm{~Hz}), 4.71(1 \mathrm{H}, \mathrm{d}, J=17.5 \mathrm{~Hz}), 3.78-3.75(1 \mathrm{H}, \mathrm{m}), 3.48-3.42(1 \mathrm{H}$, $\mathrm{m})$, 2.77-2.73 $(1 \mathrm{H}, \mathrm{m}), 2.49-2.46(1 \mathrm{H}, \mathrm{m}), 2.34(3 \mathrm{H}, \mathrm{s}) ;{ }^{13} \mathrm{C}$ NMR $(126$ $\left.\mathrm{MHz}, \mathrm{CDCl}_{3}\right) \delta 184.9,145.2,143.1,138.0,127.8,127.5,136.4,135.2$ $124.7,130.8,130.3,129.4,128.1,126.8,126.3,125.6,125.0,123.1$, 121.0, 119.5, 111.1, 63.7, 43.0, 29.3, 21.4; IR (film, $\mathrm{cm}^{-1}$ ) 3346, 3029, $2946,2861,1633,1572,1525,1446,1415,1343,1273,1251,1156$ 1061, 1019, 992, 939, 852, 1019, 992, 939, 852, 789, 752, 704, 668; HRMS (FAB) calcd for $\mathrm{C}_{27} \mathrm{H}_{24} \mathrm{~N}_{3} \mathrm{O}_{5} \mathrm{~S}[\mathrm{M}+\mathrm{H}]^{+}$502.1437; Found: $\mathrm{m} / \mathrm{z}$ 502.1454 .

Compound 4a: To a solution of 5 a $(50 \mathrm{mg}, 0.106 \mathrm{mmol})$ in $\mathrm{CH}_{2} \mathrm{Cl}_{2}$ (3 $\mathrm{mL})$ was added ${ }^{\mathrm{t}} \mathrm{BuOCl}(0.018 \mathrm{ml}, 0.159 \mathrm{mmol})$, and the mixture was stirred at room temperature for $1 \mathrm{~h}$. Concentration under reduced pressure gave the crude material, and used the next reaction without purification. To the solution of the residue in $\mathrm{EtOH}(2 \mathrm{ml})$ and $\mathrm{CH}_{2} \mathrm{Cl}_{2}$ (3 $\mathrm{mL}$ ) was added $\mathrm{HCl}\left(1 \mathrm{M}\right.$ in $\left.\mathrm{Et}_{2} \mathrm{O}, 0.10 \mathrm{ml}\right)$, and the mixture was stirred at room temperature for $3 \mathrm{~h}$. The reaction mixture was concentrated under reduced pressureand purified by flash column chromatography on silica gel (20\% EtOAc/hexane) to give $4 a$ ( $26 \mathrm{mg}, 54 \%)$ as a colorless oil: [a] $]_{\mathrm{D}^{21}}$ $-3.9^{\circ}\left(c 1.28, \mathrm{CHCl}_{3}\right) ;{ }^{1} \mathrm{H}$ NMR $\left(\mathrm{CDCl}_{3}\right) \delta 8.33(1 \mathrm{H}, \mathrm{s}), 7.51(2 \mathrm{H}, \mathrm{d}, J=$ $8.0 \mathrm{~Hz}), 7.23(1 \mathrm{H}, \mathrm{t}, J=7.7 \mathrm{~Hz}), 7.16(2 \mathrm{H}, \mathrm{d}, J=8.3 \mathrm{~Hz}), 6.93(1 \mathrm{H}, \mathrm{d}, J=$ $7.7 \mathrm{~Hz}), 6.85(1 \mathrm{H}, \mathrm{d}, J=7.7 \mathrm{~Hz}), 5.77-5.69(2 \mathrm{H}, \mathrm{m}), 5.21(1 \mathrm{H}, \mathrm{d}, J=10.2$ $\mathrm{Hz})$, 4.85-4.81 $(2 \mathrm{H}, \mathrm{m}), 4.09-4.06(1 \mathrm{H}, \mathrm{m}), 3.92-3.89(1 \mathrm{H}, \mathrm{m}), 2.51-2.49$ $(1 \mathrm{H}, \mathrm{m}), 2.36(3 \mathrm{H}, \mathrm{s}), 1.55-1.50(1 \mathrm{H}, \mathrm{m}), 1.12(3 \mathrm{H}, \mathrm{d}, J=6.3 \mathrm{~Hz}), 1.05$ $(3 \mathrm{H}, \mathrm{d}, J=6.3 \mathrm{~Hz}) ;{ }^{13} \mathrm{C}$ NMR $\left(126 \mathrm{MHz}, \mathrm{CDCl}_{3}\right) \delta 175.5,167.2,143.2$, $142.2,137.9,137.8,135.1,129.5,129.0,126.9,126.8,123.6,120.4$, 109.6, 70.1, 63.2, 59.3, 41.8, 29.7, 21.4, 21.1 (x2); IR (film, $\mathrm{cm}^{-1}$ ) 3302, 2987, 2939, 1740,1713,1617, 1601, 1494, 1459, 1405, 1388, 1375, $1330,1304,1266,1215,1157,1122,1038,986,943,914,874,807$ HRMS (FAB) calcd for $\mathrm{C}_{24} \mathrm{H}_{27} \mathrm{~N}_{2} \mathrm{O}_{5} \mathrm{~S}[\mathrm{M}+\mathrm{H}]^{+}$455.1641; Found: $\mathrm{m} / \mathrm{z}$ 455.1647 .

Compound 4c: $4 \mathrm{c}$ was obtained by following the procedure for $4 \mathrm{a}:[\mathrm{\alpha}] \mathrm{D}^{21}$ $-8.7^{\circ}\left(c 0.46, \mathrm{CHCl}_{3}\right) ;{ }^{1} \mathrm{H}$ NMR $\left(\mathrm{CDCl}_{3}\right) \delta 9.18(1 \mathrm{H}, \mathrm{s}), 7.45(2 \mathrm{H}, \mathrm{t}, \mathrm{J}=$ $8.0 \mathrm{~Hz}), 7.21(1 \mathrm{H}, \mathrm{t}, J=7.7 \mathrm{~Hz}), 7.15(2 \mathrm{H}, \mathrm{t}, J=6.4 \mathrm{~Hz}), 6.98(1 \mathrm{H}, \mathrm{d}, J=$ $7.7 \mathrm{~Hz}), 6.87(1 \mathrm{H}, \mathrm{d}, J=8.0 \mathrm{~Hz}), 5.89-5.87(1 \mathrm{H}, \mathrm{m}), 5.67(1 \mathrm{H}, \mathrm{br} \mathrm{s}), 5.22$ $(1 \mathrm{H}, \mathrm{d}, J=10.5 \mathrm{~Hz}), 5.06-5.02(1 \mathrm{H}, \mathrm{m}), 4.25(1 \mathrm{H}, \mathrm{t}, J=13.6 \mathrm{~Hz}), 4.03$ $(1 \mathrm{H}, \mathrm{d}, J=15.8 \mathrm{~Hz}), 3.02(3 \mathrm{H}, \mathrm{s}), 2.95(3 \mathrm{H}, \mathrm{s}), 2.48-2.45(1 \mathrm{H}, \mathrm{m}), 2.36$ $(3 \mathrm{H}, \mathrm{s}), 1.38-1.34(1 \mathrm{H}, \mathrm{m}) ;{ }^{13} \mathrm{C}$ NMR $\left(126 \mathrm{MHz}, \mathrm{CDCl}_{3}\right) \delta 175.8,169.0$, $143.1,142.3,138.5,137.7,134.7,129.5,128.7,127.4,126.8,123.5$, 119.6, 109.5, 63.4, 60.0 (x2), 57.9, 42.0, 33.5, 31.2, 21.4; IR (film, $\left.\mathrm{cm}^{-1}\right)$; $3257,2942,2865,2822,1729,1658,1458,1330,1247,1158,984,868$, $816,745,662,605,544,522,509,507$; HRMS (FAB) calcd for $\mathrm{C}_{23} \mathrm{H}_{26} \mathrm{~N}_{3} \mathrm{O}_{5} \mathrm{~S}[\mathrm{M}+\mathrm{H}]^{+}$456.1593; Found: $m / z 456.1608$

Compound $4 \mathrm{~d}$ : $\mathbf{4 d}$ was obtained by following the procedure for $\mathbf{4 a}$ $[\mathrm{a}]_{\mathrm{D}}{ }^{22}-59.9^{\circ}\left(c 1.03, \mathrm{CHCl}_{3}\right) ;{ }^{1} \mathrm{H} \mathrm{NMR}\left(\mathrm{CDCl}_{3}\right) \delta 8.01(1 \mathrm{H}, \mathrm{d}, J=8.0 \mathrm{~Hz})$, $7.91(1 \mathrm{H}, \mathrm{s}), 7.56-7.50(4 \mathrm{H}, \mathrm{m}), 7.29-7.28(1 \mathrm{H}, \mathrm{m}), 7.19(2 \mathrm{H}, \mathrm{d}, J=8.0$ $\mathrm{Hz}), 7.02(1 \mathrm{H}, \mathrm{d}, J=7.7 \mathrm{~Hz}), 6.91(1 \mathrm{H}, \mathrm{s}), 6.79(1 \mathrm{H}, \mathrm{d}, J=7.7 \mathrm{~Hz}), 6.17-$ $6.11(1 \mathrm{H}, \mathrm{m}), 5.74(1 \mathrm{H}, \mathrm{s}), 5.18(1 \mathrm{H}, \mathrm{d}, J=10.3 \mathrm{~Hz}), 5.00(1 \mathrm{H}, \mathrm{d}, J=17.2$ $\mathrm{Hz}), 4.03-3.99(2 \mathrm{H}, \mathrm{m}), 2.68(1 \mathrm{H}, \mathrm{d}, J=14.6 \mathrm{~Hz}), 2.38(3 \mathrm{H}, \mathrm{s}), 1.91-1.85$
$(1 \mathrm{H}, \mathrm{m}) ;{ }^{13} \mathrm{C} \mathrm{NMR}\left(126 \mathrm{MHz}, \mathrm{CDCl}_{3}\right) \delta 194.5,174.3,146.7,143.3,141.4$ $141.2,137.6,134.9,133.0,132.8,131.0,129.8,129.6,127.2,126.9$, 124.5, 124.3, 124.0, 118.8, 109.5, 69.3, 66.6, 31.4, 21.5, 14.1; IR (film, $\left.\mathrm{cm}^{-1}\right)$; 2979, 2913, 1743, 1716, 1541, 1233, 1087, 965, 914, 744; HRMS (FAB) calcd for $\mathrm{C}_{27} \mathrm{H}_{24} \mathrm{~N}_{3} \mathrm{O}_{6} \mathrm{~S}[\mathrm{M}+\mathrm{H}]^{+}$518.1386; Found: $\mathrm{m} / \mathrm{z} 518.1381$.

Compound 13: To a solution of $5 \mathrm{~b}(40 \mathrm{mg}, 0.105 \mathrm{mmol})$ in $\mathrm{CH}_{2} \mathrm{Cl}_{2}$ (2 $\mathrm{mL})$ was added ${ }^{\mathrm{t}} \mathrm{BuOCl}(0.018 \mathrm{ml}, 0.158 \mathrm{mmol})$, and the mixture was stirred at room temperature for $1 \mathrm{~h}$. Concentration under reduced pressure gave the crude material, and used the next reaction without purification. To the solution of the residue in $\mathrm{EtOH}(2 \mathrm{ml})$ and $\mathrm{CH}_{2} \mathrm{Cl}_{2}$ (3 $\mathrm{mL}$ ) was added $\mathrm{HCl}\left(1 \mathrm{M}\right.$ in $\mathrm{Et}_{2} \mathrm{O}, 0.10 \mathrm{~mL}$ ), and the mixture was stirred at room temperature for $3 \mathrm{~h}$. The reaction mixture was concentrated under reduced pressure and purified by flash column chromatography on silica gel (20\% EtOAc/hexane) to give $13(28 \mathrm{mg}, 73 \%)$ as a white solid: $[\mathrm{a}]_{\mathrm{D}}{ }^{23}-26.0^{\circ}\left(\mathrm{c} 0.10, \mathrm{CHCl}_{3}\right) ;{ }^{1} \mathrm{H}$ NMR $\left(\mathrm{CDCl}_{3}\right) \delta 8.62(1 \mathrm{H}, \mathrm{s}), 7.54(2 \mathrm{H}, \mathrm{d}$, $J=8.0 \mathrm{~Hz}), 7.17(3 \mathrm{H}, \mathrm{t}, J=8.3 \mathrm{~Hz}), 6.90(1 \mathrm{H}, \mathrm{d}, J=7.7 \mathrm{~Hz}), 6.81(1 \mathrm{H}, \mathrm{d}$, $J=7.7 \mathrm{~Hz}), 5.82-5.74(2 \mathrm{H}, \mathrm{m}), 5.31(1 \mathrm{H}, \mathrm{t}, J=5.2 \mathrm{~Hz}), 4.76(1 \mathrm{H}, \mathrm{t}, J=$ 8.7 Hz), 4.20-4.17 (1H, m), 3.55-3.50 (2H, m), 2.36 (3H, s), 2.17-2.15 (1H, $\mathrm{m}), 1.49-1.44(1 \mathrm{H}, \mathrm{m}) ;{ }^{13} \mathrm{C} \mathrm{NMR}\left(126 \mathrm{MHz}, \mathrm{CDCl}_{3}\right) \delta 178.7,143.2,140.9$, $137.9,136.9,134.9,129.7,129.5,128.3,127.8,127.0,126.9,122.6$ 120.4, 109.3, 63.0, 46.1, 44.6, 28.5, 21.4; IR (film, $\mathrm{cm}^{-1}$ ) 3300, 2946, $2863,1705,1617,1494,1460,1404,1327,1249,1196,1155,1014,970$, 946, 908, 855, 809, 781, 727, 710, 659; HRMS (FAB) calcd for $\mathrm{C}_{20} \mathrm{H}_{20} \mathrm{~N}_{2} \mathrm{O}_{3} \mathrm{~S}[\mathrm{M}]^{+} 368.1195$; Found: $m / z 368.1195$.

Compound 23 (Table 2, entry 5): To a solution of $\mathbf{5 d}(12.2 \mathrm{mg}, 0.0244$ $\mathrm{mmol})$ in $\mathrm{CH}_{2} \mathrm{Cl}_{2}(2 \mathrm{~mL})$ was added ${ }^{\mathrm{BuOCl}}(4.1 \mu \mathrm{L}, 0.037 \mathrm{mmol})$, and the mixture was stirred at room temperature for $1 \mathrm{~h}$. Concentration under reduced pressure gave the crude material, used the next reaction without purification. To the solution of residue in $\mathrm{EtOH}(2 \mathrm{~mL})$ was added conc. $\mathrm{HCl}(1 \mu \mathrm{L})$, and the mixture was stirred at room temperature for $30 \mathrm{~min}$ Iron $(6.8 \mathrm{mg}, 0.122 \mathrm{mmol})$ and water $(0.50 \mathrm{~mL})$ were added to the solution, and the mixture was refluxed for $3 \mathrm{~h}$. After reaction mixture was filtered through a pad of Celite, and concentration under reduced pressure. The residue was purified by flash column chromatography on silica gel (30\% EtOAc/hexane) to give $23(5.4 \mathrm{mg}, 47 \%)$ as a colorless oil: [a] $]^{23}-32.7^{\circ}\left(c 0.09, \mathrm{CHCl}_{3}\right) ;{ }^{1} \mathrm{H}$ NMR $\left(\mathrm{CDCl}_{3}\right) \delta 9.51(1 \mathrm{H}, \mathrm{s}), 8.67$ $(1 \mathrm{H}, \mathrm{d}, J=8.3 \mathrm{~Hz}), 8.01(1 \mathrm{H}, \mathrm{d}, J=8.0 \mathrm{~Hz}), 7.66(2 \mathrm{H}, \mathrm{d}, J=8.0 \mathrm{~Hz})$, 7.41-7.29 $(3 \mathrm{H}, \mathrm{m}), 7.11-7.10(4 \mathrm{H}, \mathrm{m}), 6.09(1 \mathrm{H}, \mathrm{s}), 5.90-5.84(1 \mathrm{H}, \mathrm{m})$, $5.20(1 \mathrm{H}, \mathrm{d}, J=10.3 \mathrm{~Hz}), 4.76(1 \mathrm{H}, \mathrm{d}, J=16.9 \mathrm{~Hz}), 4.14(1 \mathrm{H}, \mathrm{d}, J=14.0$ $\mathrm{Hz}), 3.70-3.65(2 \mathrm{H}, \mathrm{m}), 3.39(1 \mathrm{H}, \mathrm{d}, J=15.8 \mathrm{~Hz}), 2.31(3 \mathrm{H}, \mathrm{s}) ;{ }^{13} \mathrm{C} \mathrm{NMR}$ $\left(126 \mathrm{MHz}, \mathrm{CDCl}_{3}\right) \delta 143.2,137.8,137.7,134.9,134.2,133.7,132.1$, $131.1,129.5,128.4,127.8,127.0,124.5,124.1,123.3,123.0,119.6$ 116.7, 116.4, 115.2, 115.1, 112.9, 64.1, 43.1, 31.2, 21.4; IR(film, $\left.\mathrm{cm}^{-1}\right)$ $3219,3153,3080,2936,2855,1716,1590,1493,1427,1409,1377$, $1339,1283,1157,1050,1015,795,749,706,665$; HRMS (ESI) calcd for $\mathrm{C}_{27} \mathrm{H}_{22} \mathrm{~N}_{3} \mathrm{O}_{3} \mathrm{~S}[\mathrm{M}-\mathrm{H}]$ ] 468.1387 ; Found: $m / z 468.1374$.

Compound 21: To a solution of $5 \mathbf{d}(30 \mathrm{mg}, 0.060 \mathrm{mmol})$ in $\mathrm{CH}_{2} \mathrm{Cl}_{2}$ (2 $\mathrm{mL}$ ) was added ${ }^{\mathrm{t}} \mathrm{BuOCl}(10 \mu \mathrm{L}, 0.090 \mathrm{mmol})$, and the mixture was stirred at room temperature for $1 \mathrm{~h}$. Concentration under reduced pressure gave the crude material, used the next reaction without purification. To the solution of residue in $\mathrm{EtOH}(4 \mathrm{~mL})$ was added conc. $\mathrm{HCl}(1 \mu \mathrm{L})$, and the mixture was stirred at room temperature for $30 \mathrm{~min}$. The reaction mixture was then quenched with water, extracted with EtOAc, washed with water and brine, dried over $\mathrm{Na}_{2} \mathrm{SO}_{4}$. After concentration under reduced pressure, purification by flash column chromatography on silica gel $(40 \%$ EtOAc/hexane) gave $21(31.9 \mathrm{mg}, 98 \%)$ as a white amorphous: [a] ${ }_{\mathrm{D}}{ }^{21}$ $+42.7^{\circ}\left(c 0.51, \mathrm{CHCl}_{3}\right) ;{ }^{1} \mathrm{H} \mathrm{NMR}\left(\mathrm{CDCl}_{3}\right) \delta 7.82(1 \mathrm{H}, \mathrm{d}, J=8.0 \mathrm{~Hz}), 7.52$ $7.45(3 \mathrm{H}, \mathrm{m}), 7.36(1 \mathrm{H}, \mathrm{t}, J=7.7 \mathrm{~Hz}), 7.22-7.16(4 \mathrm{H}, \mathrm{m}), 7.07(1 \mathrm{H}, \mathrm{d}, J=$ $7.4 \mathrm{~Hz}), 6.34(1 \mathrm{H}, \mathrm{d}, J=7.7 \mathrm{~Hz}), 5.97-5.91(1 \mathrm{H}, \mathrm{m}), 5.73(1 \mathrm{H}, \mathrm{s}), 5.09$ $(1 \mathrm{H}, \mathrm{d}, J=10.6 \mathrm{~Hz}), 4.90(1 \mathrm{H}, \mathrm{d}, J=17.2 \mathrm{~Hz}), 4.33-4.29(2 \mathrm{H}, \mathrm{m}), 4.10$ $(3 \mathrm{H}, \mathrm{td}, J=13.1,5.7 \mathrm{~Hz}), 2.72-2.70(1 \mathrm{H}, \mathrm{m}), 2.37(3 \mathrm{H}, \mathrm{s}), 1.24(3 \mathrm{H}, \mathrm{dd}, J$ 
$=14.5,7.3 \mathrm{~Hz}) ;{ }^{13} \mathrm{C} \mathrm{NMR}\left(126 \mathrm{MHz}, \mathrm{CDCl}_{3}\right) \delta 194.1,178.1,155.6,147.8$, 143.2, 139.0, 137.8, 134.7, 131.9, 131.54, 131.51, 131.3, 130.0, 129.5, 126.90, 128.87, 125.2, 124.4, 119.9, 118.2, 68.3, 66.4, 63.8, 41.5, 29.7, 21.4, 13.7; IR (film, $\mathrm{cm}^{-1}$ ) 3028, 2938, 2858, 1714, 1695, 1612, 1573, $1532,1475,1434,1342,1299,1245,1224,1157,1012,882,845,813$, 749, 706, 690, 662; HRMS (ESI) calcd for $\mathrm{C}_{29} \mathrm{H}_{28} \mathrm{~N}_{3} \mathrm{O}_{6} \mathrm{~S}[\mathrm{M}+\mathrm{H}]^{+}$ 546.1693; Found: $m / z 546.1697$.

Compound 22: To a solution of 21 ( $31.9 \mathrm{mg}, 0.0585 \mathrm{mmol})$ in EtOH (6 $\mathrm{mL}$ ) and water $(1.5 \mathrm{~mL})$ was added iron $(65 \mathrm{mg}, 1.16 \mathrm{mmol})$ and $\mathrm{NH}_{4} \mathrm{Cl}$ (65 mg, $1.21 \mathrm{mmol}$, purchased from KANTO Chemicals). The mixture was refluxed for $1 \mathrm{~h}$. The reaction mixture was then quenched with water, extracted with EtOAc, washed with water and brine, dried over $\mathrm{Na}_{2} \mathrm{SO}_{4}$. After concentration under reduced pressure, purification by flash column chromatography on silica gel (50\% EtOAc/hexane) gave $22(11.9 \mathrm{mg}$, $43 \%)$ as a white amorphous: $[\alpha]_{D^{27}}+140.7^{\circ}\left(\mathrm{c} 0.12, \mathrm{CHCl}_{3}\right) ;{ }^{1} \mathrm{H}$ NMR $\left(\mathrm{CDCl}_{3}\right) \delta 7.71(1 \mathrm{H}, \mathrm{d}, J=7.7 \mathrm{~Hz}), 7.50-7.46(3 \mathrm{H}, \mathrm{m}), 7.30-7.27(3 \mathrm{H}, \mathrm{m})$, $7.14(2 \mathrm{H}, \mathrm{d}, J=8.0 \mathrm{~Hz}), 7.06-7.03(2 \mathrm{H}, \mathrm{m}), 6.74-6.67(1 \mathrm{H}, \mathrm{m}), 5.75(1 \mathrm{H}$, s), $5.35(1 \mathrm{H}, \mathrm{d}, J=10.6 \mathrm{~Hz}), 5.21(1 \mathrm{H}, \mathrm{d}, J=17.2 \mathrm{~Hz}), 3.89-3.86(1 \mathrm{H}, \mathrm{m})$ 3.46-3.44 $(1 \mathrm{H}, \mathrm{m}), 2.42-2.33(5 \mathrm{H}, \mathrm{m}), 1.72(1 \mathrm{H}, \mathrm{t}, J=12.6 \mathrm{~Hz}) ;{ }^{13} \mathrm{C}$ NMR $\left(126 \mathrm{MHz}, \mathrm{CDCl}_{3}\right) \delta 199.4,166.6148 .1,143.2,141.7,137.4,135.5$, $129.6,129.2,127.0,126.6,126.2,126.0,122.3,120.3,116.0,114.6$, 85.0, 61.1, 34.5, 28.2, 21.4; IR (film, $\mathrm{cm}^{-1}$ ) 3150, 3086, 3040, 2960, 2923, $2857,1702,1630,1607,1570,1476,1431,1285,1325,1266,1232$, 1156, 1087, 1019, 990, 910, 875, 813, 741, 668; HRMS (FAB) calcd for $\mathrm{C}_{27} \mathrm{H}_{24} \mathrm{~N}_{3} \mathrm{O}_{3} \mathrm{~S}[\mathrm{M}+\mathrm{H}]^{+}$470.1538; Found: $m / z 470.1545$

\section{Acknowledgements}

This work was supported in part by a Research Grant from the Uehara Memorial Foundation (C.T.).

Keywords: communesin $\cdot$ aurantioclavine $\cdot$ oxidative rearrangement $\cdot$ reductive cyclization $\cdot 2$-ethoxyindolenine

[1] A. Numata, C. Takahashi, Y. Ito, T. Takada, K. Kawai, Y. Usami, E. Matsumura, M. Imachi, T. Ito, T. Hasegawa, Tetrahedron Lett. 1993, 34 2355.

[2] a) R. Jadulco, R. A. Edrada, R. Ebel, A. Berg, K. Schaumann, V. Wray, K. Steube, P. Proksch, J. Nat. Prod. 2004, 67, 78; b) H. Hayashi, H. Matsumoto, K. Akiyama, Biosci. Biotechnol. Biochem. 2004, 68, 753; c) P. W. Dalsgaard, J. W. Blunt, M. H. G. Munro, J. C. Frisvad, C. Christophersen, J. Nat. Prod. 2005, 68, 258.

[3] a) P. Siengalewicz, T. Gaich, J. Mulzer, Angew. Chem. Int. Ed. 2008, 47, 8170; b) Z. Zuo, D. Ma, Israel J. Chem. 2011, 51, 434; c) J. H. George, R. M. Adlington, Synlett 2008, 2093; d) B. M. Trost, Y. Zhang, Chem. Eur. J. 2011, 17, 2916; e) A. W. Schammel, G. Chiou, N. K. Garg, Org. Lett. 2012, 14, 4556; f) J. Danielsson, P. Somfai, Org. Lett. 2014, 16, 784; g) A. Sanzone, P. Somfai, Eur. J. Org. Chem. 2015, 3441 .

[4] a) J. Yang, H. Song, X. Xiao, J. Wang, Y. Qin, Org. Lett. 2006, 8, 2187 b) J. Yang, H. Wu, L. Shen, Y. Qin, J. Am. Chem. Soc. 2007, 129, 13794; c) H. Wu, X. Xiao, Y. Qin, Synlett 2011, 907.

[5] a) P. Liu, J. H. Seo, S. M. Weinreb, Angew. Chem. Int. Ed. 2010, 49, 2000; b) J. H. Seo, P. Liu, S. Weinreb, J. Org. Chem. 2010, 75, 2667.
[6] a) Z. Zuo, W. Xie, D. Ma, J. Am. Chem. Soc. 2010, 132, 13226; b) Z. Zuo, D. Ma, Angew. Chem. Int. Ed. 2011, 50, 12008

[7] a) S. L. Crawley, R. L. Funk, Org. Lett. 2003, 5, 3169; b) J. Belmar, R. L. Funk, J. Am. Chem. Soc. 2012, 134, 16941

[8] A. G. Kozlovskii, T. F. Solov'eva, V. G. Sakharovskii, V. M. Adanin, Dokl. Akad. Nauk SSSR 1981, 260, 230.

[9] a) J. A. May, R. K. Zeidan, B. M. Stoltz, Tetrahedron Lett. 2003, 44 1203; b) J. A. May, B. Stoltz, Tetrahedron 2006, 62, 5262.

[10] L. J. Wigley, P. G. Mantle, D. A. Perry, Phytochemistry, 2006, 67, 561.

[11] a) S.-J. Han, F. Vogt, S. Krishnan, J. A. May, M. Gatti, S. C. Virgil, B. M. Stoltz, Org. Lett. 2014, 16, 3316; b) S.-J. Han, F. Vogt, J. A. May, S. Krishnan, M. Gatti, S. C. Virgil, B. M. Stoltz, J. Org. Chem. 2015, 80, 528; c) C. W. Lee, S.-J. Han, S. C. Virgil, B. M. Stoltz, Tetrahedron 2015, 71, 3666 .

[12] H.-C. Lin, G. Chiou, Y.-H. Chooi, T. C. McMahon, W. Xu, N. K. Garg, Y. Tang, Angew. Chem. Int. Ed. 2015, 54, 3004.

[13] S. Suetsugu, C. Tsukano, Y. Takemoto, Org. Lett. 2014, 16, 996.

[14] a) W. A. Moradi, S. L. Buchwald, J. Am. Chem. Soc. 2001, 123, 7996; b) S. Lee, N. A. Beare, J. F. Hartwig, J. Am. Chem. Soc. 2001, 123, 8410 ; c) S. Lee, J. F. Hartwig, J. Org. Chem. 2001, 66, 3402; d) M. Jørgensen, S. Lee, X. Liu, J. P. Wolkowski, J. F. Hartwig, J. Am. Chem. Soc. 2002, 124, 12557; e) D. Solé, O. Serrano, J. Org. Chem. 2008, 73, 2476 ; f) A. G. K. Reddy, G. Satyanarayana, Tetrahedron 2012, 68 , 8003.

[15] T. Ishida, C. Tsukano, Y. Takemoto, Chem. Lett. 2013, 41, 44.

[16] Selected examples of the synthesis of indole alkaloids using an oxidative rearrangement reaction, see: a) C. Poriel, M. Lachia, C Wilson, J. R. Davies, C. J. Moody, J. Org. Chem. 2007, 72, 2978; b) M. Lachia, C. Poriel, A. M. Z. Slawinc, C. J. Moody Chem. Commun. 2007 286; c) T. Lindel, L. Bräuchle, G. Golz, P. Böhrer Org. Lett. 2007, 9, 283; d) P. S. Baran, J. M. Richter J. Am. Chem. Soc. 2005, 127, 15394 e) H. Takayama, R. Fujiwara, Y. Kasai, M. Kitajima, N. Aimi, Org. Lett. 2003, 5, 2967; f) M. Ito, C. W. Clark, M. Mortimore, J. B. Goh, S. F. Martin; J. Am. Chem. Soc. 2001, 123, 8003; g) S. Edmondson, S. J. Danishefsky, L. Sepp-Lorenzino, N. Rosen, J. Am. Chem. Soc. 1999 121, 2147; h) S. D. Edmondson, S. J. Danishefsky, Angew. Chem. Int. Ed. 1998, 37, 1138; i) R. Stahl, H.-J. Borschberg, P. Acklin, Helv. Chim. Acta 1996, 79, 1361; j) H. Takayama, K. Masubuchi, M. Kitajima, N. Aimi, S.-i. Sakai, Tetrahedron 1989, 45, 1327; k) D. V. C. Awang, A. Vincent, D. Kindack. Can. J. Chem. 1984, 62, 2667; I) A. Walser, J. F. Blount, R. I. Fryer, J. Org. Chem. 1973, 38, 3077; m) K. V. Lichman J. Chem. Soc. (C), 1971, 2539; n) T. Oishi, M. Nagai, T. Onuma, H. Moriyama, K. Tsutae, M. Ochiai, Y. Ban, Chem. Pharm. Bull. 1969, 17, 2306; o) N. Finch, W. I. Taylor, J. Am. Chem. Soc. 1962, 84, 3871.

[17] The synthesis of compound 6 was reported in reference 13.

[18] Imine 8 was a mixture of diastereomers

[19] Several ligands were evaluated, including $\mathrm{PPh}_{3}, \mathrm{PCy}_{3} \cdot \mathrm{HBF}_{4}, \mathrm{NHC}$ and dialkylbiarylphosphine ligands.

[20] Several bases were examined, including $\mathrm{Cs}_{2} \mathrm{CO}_{3}$, LiHMDS, NaHMDS, $\mathrm{KO} \mathrm{Bu}$ and $\mathrm{NaO}$ 'Bu.

[21] The same type of fragmentation was also reported by Trost and coworkers: see ref. $3 d$.

[22] A related side product was also reported by Westwood et al.: see N. Voûte, D. Philp, A. M. Z. Slawin, N. J. Westwood, Org. Biomol. Chem. 2010, 8, 442.

[23] The epimerization of $\mathrm{C} 11$ would give an enantiomer of communesins For synthesis of a natural enantiomer, epimerization of C7 and C2 would be required. 


\section{Entry for the Table of Contents}

\section{FULL PAPER}

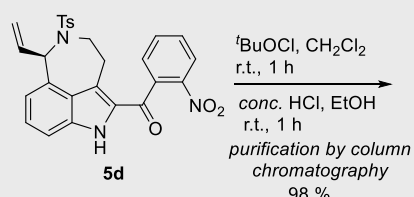
$98 \%$

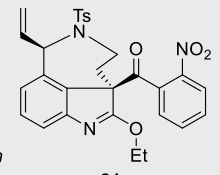

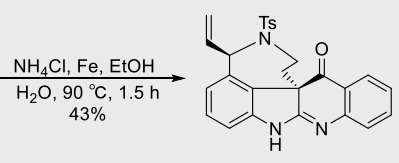

The construction of the pentacyclic skeleton of communesins has been investigated via the oxidative rearrangement of aurantioclavine derivatives, which are thought to be biosynthetic intermediates of the communesins. The $\mathrm{C} 7$ quaternary carbon center was constructed in a stereoselective manner, whilst the $\mathrm{C} 11$ stereocenter required an epimerization step. The isolation of 2-ethoxyindolenine prior to the reduction of the nitro group and cyclization was critical to the success of the

\section{Natural Product Synthesis}

Satoshi Suetsugu, Chihiro Tsukano, Yoshiji Takemoto*

Page No. - Page No.

Synthetic Studies Toward Communesins: Diastereoselective Oxidative Rearrangement of Aurantioclavine Derivatives 